\title{
Religion without ulterior motive
}

\author{
A van de Beek \\ Vrije Universiteit Amsterdam \\ The Netherlands ${ }^{1}$
}

\begin{abstract}
This article deals with the relevance of Christian faith. It is expected of religion to be of relevance to society, to inform politics, to guide people in their personal development, and so forth. The article wants to explore the argument of whether religion should be relevant at all, and what the consequences of denying the relevance of religion would be.
\end{abstract}

\section{NO ALLIANCES}

During the 1840s, there was a movement in European Judaism that argued for interaction between Judaism and contemporary culture. The notion was propagated that Jews should not stand aloof from society in their own religious and social traditions, but should participate fully in local social and cultural life. That would be better for Judaism as a living community and for the whole of society as well. Jews had an enormous amount to contribute to the well-being of all people, since they had a lot of experience in the administration of justice and in community building. This movement became very strong in Judaism. Even in 1936, Jewish author Ernst Kahler argued that (German) Jews should not oppose German politics, but should participate fully in German society, in such a way that they would be both better Germans and more motivated citizens (Kähler 1936:101-162). Nowadays, we hear similar voices among American Jews. In the context of the nineteenth century, such a plea for inculturation meant a plea for progress, as this concept was central in nineteenth century thought. Thus these Jews argued for religion allied to progress.

It is precisely at this point that the Jewish author Samuel Hirsch opened a fierce attack. He wrote:

\footnotetext{
${ }^{1}$ Prof $\mathrm{Dr}$ A van de Beek is Professor at the Vrije Universiteit Amsterdam and Professor by special appointment at the Faculty of Theology, University of Stellenbosch. This article is the product of collaboration with Prof Buitendag, Department of Dogmatics and Christian Ethics, Faculty of Theology, University of Pretoria.
} 
The subordination of religion to any other factor means the denial of religion: for if the Torah is to you the Law of God how dare you place another law above it and go along with God and His Law only as long as you thereby "progress" in other respects in the same time? ... "Religion allied to progress" - do you know, dear reader, what that means? ... It means sacrificing religion and morality to every man's momentary whim.

(Hirsch 1854, in Frank, Leaman \& Manekin 2000:393)

The core of Hirsch's argument is that religion can never be a means to any other end than itself. Religion is an end - or rather, the end - in itself. To have any other aim in religious life is nothing less than blasphemy. Orthodox Jews are very sensitive to this risk. The dietary laws of Judaism are a good example of this notion: some people argue that these laws are good because they promote health; thus, observing the law promotes good health. Abraham Heschel's (1980) response to this is similar to Hirsch's. Heschel says that these laws are about religion and cannot be transferred to another domain. The moment such a transfer takes place, the laws lose their religious character. The laws do not serve any purpose, except to allow those who observe them to be servants of the Lord: "We do not search for utility in the laws, but eternity" (Heschel 1980:269).

Religion is its own end, and it may not be instrumentalised to anything else. This statement seems tenable, and perhaps even self-evident, for all those who know what religion really is. But we must view the consequences of accepting this statement - and I think these logical consequences may come as a shock to many people, especially many contemporary Christians.

The first consequence has to do with the rationality of faith. If religion is its own end, it means we cannot use any arguments to promote our religion. We cannot argue that Christian faith is better than other religions, for the moment we use such an argument - for instance, the argument that Christianity creates the most just society, more so than other world views or religions - then a just society is put above faith. Any such argument makes faith inferior, turning it into a second-level issue. We are Christians only because we are Christians, and not because there is a good argument for being Christians. Faith is similar to the deepest human relations. We accept our children just because they are our children and not because they have characteristics that are better than those of other children, of course our children may indeed have wonderful characteristics, good manners and so on, but we love them and their characteristics because they are our children; we did not choose them because they had such characteristics. Obviously, for 
Christians, Christianity is better than any other religion, but that statement is the consequence of their being Christians and is not the cause of the worth of Christianity. Thus the proposition that religion should be without any ulterior motive has far-reaching consequences for apology and missiology.

The consequences, however, for the relation of Christian faith to other fields of life are even more striking. Few people will agree completely with an Indonesian theologian who stated: "If Christianity does not bring you progress, why should you be a Christian?" That view is the exact opposite of Hirsch's (1854) ideas. But Hirsch digs deeper. It is not blatant opportunism that he wishes to oppose. He distrusts any tendency to use religion for other aims. You cannot use faith as an instrument in order to gain something. If you do so, religion is soon delivered to the whim of the day of any person who can use it to serve his or her own interests. In this respect, Hirsch fully agrees with another Jew, Paul. Paul opposes persons "of a corrupt mind who have been robbed of the truth and who think that godliness is a means to [financial] gain" (1 Tm 6:5). Certainly godliness is a great gain - but of a totally different kind: the gain of a life in gratitude for any gift of God. But that is a consequence, not the aim of godliness.

What both Paul and Hirsch refute is an instrumentalisation of faith. And it is precisely that danger that arises in our functionalist age. We are inclined to use anything and anyone as a means to an end. That is also the case with religion. Politicians do it - as soon as a senator in the USA runs for the presidency, he becomes really "religious"; and if he was already religious he begins to speak openly about his conversion - he is a born-again Christian. This grandstanding may be obvious - nevertheless, it works.

It can also be more subtle, as is usual (and useful) in The Netherlands. Politicians speak about the important role of churches in the development of norms and values. Not only the Christian Democrats do this, but so do conservative liberals and labour politicians. In the churches themselves, it has for a long time been customary to put the following question to theologians: "What are the ethical consequences of your position?" Hirsch's (1854) position is a critique of both such politicians and such church members. You cannot use religion for to generate values. Nor can you use it to determine ethics. Certainly, faith has ethical consequences and creates high values of life; as Paul says, godliness gives great gain. But you cannot use this as an argument for the uses of religion. These consequences are not faith itself, and far less are they the aim or purpose of faith. The aim of faith is God alone - and nothing besides God. God will not give his glory to something else (Is 42:8; 48:11; 45:22-25), not even to ethics. 


\section{ALLIANCES ARE ATTRACTIVE}

Nevertheless, instrumentalisation has been the dominant culture in theology during the last centuries, and especially during the second half of the twentieth century. This approach to theology is the theological equivalent of the functionalist culture of the modern West that is increasingly dominant in a globalising world. I will give three examples that are often considered as alternatives, but from this perspective all suffer from the same disease: the use of religion for other ends, especially the interests of the person who uses the argument.

\section{$2.1 \quad$ Liberation theology}

Liberation theology is a clear example of religion with a goal. That goal is not God and his service, but political and economic liberation. The point of my critique is not that even if the groups that use a theology of this kind are successful, their society usually turns out to be either a liberal society with similar problems but different actors and powers, or an oppressive society where the winners impose their ideas on others. Instead, I would like to focus on the fact that religion is used to accomplish this political change. True religion, as conceived by Hirsch (1854), is interested in material and social issues, but never in such a way that it makes these issues the core of religion. It must be clear that they are relative, second- or even third-level questions.

This does not mean we should retreat from the world into religious mysticism. Both orthodox Judaism and Christianity are very sensitive to everything that happens in the world. They know about suffering, exploitation, persecution and corruption. They also know these facts are so deeply rooted in humankind that we cannot change them by ideologies or change our world into the utopias we strive for. It is precisely in our awareness of political or economic problems, without opposing them directly, that religion shows that the glory of God and our being in God belongs to a different category from any other issue.

Thus New Testament authors do not discuss the issues of abolishing slavery (Eph 6:5-9; Col 3:21-4:1; 1 Pt 2:18-25; Phlp) or improving the position of women (Eph 5:22-24; Col 3:18; 1 Pt 3:1-7). They plead for just relations in slavery, but not for its abolition. Certainly, in Christ, there is no difference between a free person and a slave, male and female (GI 3:28; Col 3:11). However, Paul argues that women must behave according to the customs of contemporary society. In this case, he even agrees with Peter, who says that the glory of women is in simplicity of dress and behaviour and submission to their husbands. By acting in this way, they can show that they are really free and have higher interests than emancipation or a public life. 
Modern "enlightened" Western people cannot easily understand this priority of religion and therefore they tend to oppress Moslems who understand what religion is, just as ancient society oppressed Christians who did not fit into contemporary society at that time. They feel (and felt) uneasy with people who do not strive to gain something. Therefore they suppose that there must be something very perverted and hidden in the subculture these people belong to. Other people do not understand, and therefore they blame and persecute.

Currently, the concept of liberation is dominant in mainstream contemporary Christianity. Its most comprehensive expression is the programme on Peace, Justice and Integrity of Creation of the World Council of Churches. All the energy of the world community is directed to changing the world for the better. My main problem with this is not that this approach does not help very much (it is debatable whether it has helped so far or not) and that it soaks up a lot of resources, but that it is a denial of the core of Christianity.

Early Christianity did not make any effort to change society. The early Christians were a different kind of people, a new creation, and their life was hidden in God with Christ. Their opponents did not understand that. They noticed that Christians knew very well what was going on in the world - and that Christians rejected it. The early Christians criticised ancient society. But people in the ancient world did not understand why and how. There is a beautiful, explicit example that casts some light on the discussion. The Hellenistic philosopher Celsus wrote that Christians criticised society. But what alternative did they offer? Therefore he challenged them to participate actively in administration, in order to change things for the better. Origen, in his answer in Contra Celsum, refused the invitation, saying that the Christians have a better King to serve. If we have capacities for leadership, we will employ these in the church, and even there with circumspection, for power easily perverts (Origen, in Migne 1885:75).

"Your Kingdom come" had a quite different meaning for early Christianity than it does for twentieth century mainstream Christians. It meant total submission to the will of God as King of our lives, and not an expectation of changing the world into a new society. That idea would be as alien to them as the early Christians' idea of a community that has its dwelling place in heaven would be to modern Christians. How can you be concerned with changes in the world when this world has lost its kairos and we are living in Christ, who shares our lives?

From this perspective we must also be critical of the late nineteenth century Christian emancipation movement in The Netherlands that created 


\section{Religion without ulterior motive}

specific Christian political parties to promote the public influence of Christians and their ideas. Religion was seen as a means for political power, both by Catholics (under the leadership of Schaepman) and by Neo-Calvinists (with Kuyper as their leader). Even in his own time, Kuyper was reproved by theologians such as Gunning who opposed his striving for power.

It is obvious that neither the World Council nor Kuyper rose or could rise to the standards of true religious life that are posited by both Hirsch and Origen.

It should also be clear that this does not mean that Christian faith is not about freedom. Both the New Testament and the church fathers and Reformers, in fact, the entire Christian tradition, teach that Christ brings us to freedom. But this is principally a freedom of a different kind from secular personal or political freedom (Van de Beek 1997) and, in addition, the way this freedom functions is the result of being in Christ and not an argument for faith. Paul's statement that we should beware of wishing to gain something by faith applies fully here.

\subsection{Theocracy}

Theocracy is the second example of religion with a goal. Kuyper, for example, is often reproached with aiming at political emancipation and influence, and not at a transformation of the whole of society under the Lordship of God. In short, he is accused of being merely a liberation theologian and not a theocrat! I am not sure that this critique of Kuyper is valid. When Kuyper says there is no domain in the world where Christ does not say "This is mine", a theocracy is implied (Kuyper 1930:32). The difference between Kuyper and gnesio-theocrats such as Hoedemaker (and still stronger, Van Ruler) is only that Kuyper at least distinguishes between the different spheres of life and thus defends more distance between the church, universities and the state than the theocrats advocate.

The theocratic ideal implies a close relation between faith and society in all its manifestations, including culture and the state. It is an exact expression of what Hirsch calls religion allied to progress. Perhaps the theocrats do not use the word "progress", but that is not the focus of the argument. It is the phrase "allied to". The connection between faith and any other reality is what Hirsch sees as wrong. Theocracy makes religion dependent on the state, on culture or the shape of society. Actually, these elements of the human world become idols which obscure the true God. They stand for and promote a longing for earthly power, while early Christianity was averse to any worldly power. 
We can conceive of the development of national states in Europe since the sixteenth century and later in the USA as a combination of liberation theology and theocracy. Both ideologies are combined in a powerful concept of a nation that is given or even elected by God (Smith 2003). Many nations and movements have made use of notions derived from this concept: we live in God's own country; we are the Israel of the West; we are the people of Israel on a trek through the desert to the land God will give us; there is a threefold chain of God, The Netherlands and the House of Orange together; God shaped Hungary surrounded by mountains; and so on. It is an ideology that is conspicuously expressed by Classen in a 1931 RGG article on "Volk und Volkstum": every nation has a religious base, and therefore it is absolute and will exclude all those who are different. Here we see the dangerous but logical consequence of "religion allied to" a social element: it creates exclusion and consequently results in the oppression of those who are not included.

This seems to be a strong argument for my position. We should not develop a theology that supports exclusivism and suppression. I agree we should not do so. But that is not my argument. For if it were my argument, ultimately it would be precisely an argument whereby faith is again submitted to an end. We must not proclaim the autonomy of faith because it prevents people from becoming oppressive, but for its own sake alone. Making people free from oppression is not an argument for faith, but the consequence of faith.

\subsection{Pietism}

Pehaps some readers will conclude from the above argument that pietism would be the best religious attitude - aloof from participation in society and only celebrating God's presence in personal life. That would, however, be to misunderstand the argument totally. Pietism itself is a strong example of "religion allied to ..." - often "allied to progress". That is clearly the case in modern pietism. Preachers from the USA bring their gospel to Latin America, proclaiming that if people convert to their kind of religion, they will prosper, they will have good luck and even healing in life. They call on people to become Christians in order to gain something by doing so. They are precisely the kind of preachers Paul warns Timothy against. Their message is attractive but, from the perspective of true faith, it is a lie. It is the kind of pietism we can find all over the world nowadays. It is the kind of Christianity with the effect a Korean colleague told me about. He said: "If you lay the diagram of persons attending worship over those of the stock market, they are precisely the 
same." Church members obviously consider whether church-going is a good investment.

Classic pietism is not quite as obvious in its desire for gain. But here too, we can find similar expressions. A church member said, "If I did not have my faith, I would not know how to overcome my sorrows and troubles." The underlying idea is that faith serves to overcome problems - ignoring the fact that Christian faith is often the cause of many troubles, and that it is easier to be like those who do not worry about God, as Psalm 73 says.

The deepest form of pietism says "I feel such a good Christian, precisely because I do not want to gain anything from my faith. I am the true godly person. I am pious because God is enough for me." This is religion allied to piety - the most deceptive alliance of all. It implies the justification of those who claim to be godly and the exclusion of the godless.

\section{CHRISTIANS ARE GOOD FOR SOCIETY}

In conclusion: we believe in God, only because we love and honour God, and not for any other aim or to promote any alliance. That does not mean that our faith has no impact on our life on earth. To make that clear I refer to two fields.

First, if we are Christians and our dwelling is in heaven, we do not fight for our position in the world. We can be patient, helpful, and all the other characteristics of Christian life we can find in New Testament paraenesis - no hate for enemies, no divorce, no resentment by slaves.

Justin Martyr has worked that out when he argues in his Apology $(1987: 1 ; 17 ; 29 ; 68)$ that Christians are better citizens. We must be very careful here. Justin does not use his argument for apologetic ends. He does not say: you should become a Christian because that will be better for society. That is against everything that moves early Christianity. His argument is only a counter-argument against those who say that Christians are a danger to society and a perverted people. We are not, he says. We do not lie, we do not kill, we do not steal. You can trust us, precisely because we do not have worldly interests. So, if we claim that we serve the Lord only for his own sake, it follows that we live in love and compassion with other people, precisely because we do not have anything to gain from them.

Second, we are not dependent on what happens in the world. We do not fear those who can kill the body. We fear God, who has the ultimate power to decide about our being. We do not fear persecution or suppression. The Letter to the Hebrews goes so far as to say that Christians joyfully accepted the confiscation of their property (Heb 10:34). We do not depend on possessions. We depend only on the Lord. Therefore we have no need to change the state or societal structures. On the other hand, Christians striving 
for martyrdom were also condemned in early Christianity. Martyrdom would also imply an alliance, as if the relation with the Lord was dependent on martyrdom.

It is a subtle balance, which we can find in Romans 13. That is not a plea for theocracy. Early Christianity rejects divine claims by the government. That is precisely one of the reasons for their persecution. Paul says in Romans 13: thank God there is a government and that we can at least live in the pax Romana. Of course, this is not the kingdom of God. But God shows his grace to us by preserving us in peace. That is better than revolt and civil war - as some Jews were already discussing at that time (Van Unnik 1951:552).

Our life in Christ is enough, and if we have a relatively peaceful life on earth, that is an additional gift of God for which we can thank Him. That is the position of early Christianity, and of the greatest authors of later church history. A good example can be found in John Calvin's thought. We know life on earth will not be easy. That will, however, not jeopardise Christian life. For the core of it is the meditatio futurae vitae, that means our being in Christ in his life in heaven. Calvin shares the opinion of a famous Irenaeus fragment: "The most important task of a Christian is thinking of death" (Fragment XI, Migne 1855, PG 7:1234). If besides this we receive food and clothing, we must be very grateful and thank the Lord for His grace. If we have a good government we will also be grateful, and if not, we will not complain and not revolt either, for Calvin is deeply convinced that earthly society will never be the expression of God's kingdom. The only presence of God is in Christ and therefore in the proclamation of the Word and the celebration of the sacraments that are the memory of Christ.

How Calvin thinks about Christian life (and thus Christian ethics) and the state can be illustrated by two chapters of his Institutes. In III, 19 he speaks about Christian freedom as the core of Christian life. There, the core concept is humility. There he speaks in line with New Testament paraenesis, advocating endurance, patience and love. In the very last chapter of the Institutes he speaks about the government. Here the core concept is not humilitas but aequitas (Van de Beek 2003a). We must not translate this term as "equality", because that word is coloured by the Enlightenment ideal of the equality of all human beings. It is better translated as "equilibrium" or "balance" (Van de Beek 2003b). Calvin is very aware that all human beings are not equal. That is precisely why the government must bring balance in society. We must be grateful if we have a government that can do so. If we have an opportunity to contribute to it, we should do so (Balke 1973:59-64). In that respect, Calvin disagrees with Origen. But we should not contribute to 
government for the cause of theocracy, but merely for the sake of earthly balance.

Aequitas is needed precisely because the government is not divine. Calvin refutes kings who make absolute claims (Institutes IV, 20, 8). An absolute monarch is inclined to want to rule as a god, not taking into account that he is a fallible, powerless human being. Precisely in order to avoid a situation where religion is allied to earthly power, we need a shared leadership by wise people. Calvin is not a democrat, for he is aware of how easily the masses can be moved by wicked leaders. Calvin always searches for balance. But even if society is not in balance, our faith is not dependent on such balance. On behalf of the people entrusted to them, lower governments can oppose higher governments - not on behalf of their own power, but willingly suffering on behalf of their people. Even then they must not act with violence, but only seek to convince the other powers of the need for change.

\section{CONCLUSION}

That we must serve the Lord without any ulterior motive is a notion deeply rooted in Jewish, and thus Christian, religion. A noteworthy text is Hab 3:17: "Though the fig tree does not bud and there are no grapes on the vines, though the olive crop fails and the fields produce no food, though there are no sheep in the pen and no cattle in the stalls, yet I will rejoice in the Lord, I will be joyful in God my Saviour." If we lose everything - nevertheless, we can praise the Lord. Psalm 73 shows an awareness of the seductiveness of worldly life - but ends with the confession that even if heart and flesh will fail, God will be the strength of my heart and my portion for ever. And it is good to be near Him. That is the difference between people whose reward is in this life and those whose reward is the Lord, say other psalms (e g, Ps 17:14; 49).

The logical consequence of this is that true godliness can only become clear if you lose everything without any reason. That is the test the book of Job tells us about. It is not about suffering as such, but about unjust suffering. "As surely as God lives who has denied my justice," says Job (Job 27:2). But even in that extreme case, Job held fast to the Lord as the only judge. And he was right (see Van de Beek 1992:90-92). It is the same perseverance as Jesus showed. Jesus died with the cry "My God, my God, why have you forsaken me?" (Mk 15:34). And Paul says that God is "He who betrayed (eparadosen) his own Son" (Rm 8:32). Nevertheless, Jesus says: "Father, into your hands I commit my spirit" (Lk 23:46). That is the fulfilment of ultimate godliness. It is finished. Tetelesthai (Jn 19:30). That has to do with the deepest meaning of the edei, the necessity of Christ's suffering and death. 
Job did not know about what happened in heaven. He simply experienced his unjust fate. Otherwise, suffering would lose its sting. Suffering can never become an ideal. It is meant to be painful. Therefore orthodox Christianity does not promote an ideal of poverty. If poverty were to be the expression of true godliness, we could again claim and manipulate our relation to God. It is precisely the "not willed" suffering that challenges our faith to hold fast to the Lord. But we can be grateful for every day that we are not submitted to a test like that which Job had to endure. God is good to us, by not making our burden too heavy. But at the moment that a dark fate overtakes us, ultimate godliness is to endure joyfully, as Hebrews says.

"Religion without ulterior motive." That is the true godly attitude to which both Christians and Jews, and actually all truly religious people, are called. We serve the Lord for nothing, as the book of Job says (1:9). That is as far as human beings are involved.

Christian doctrine also knows that we must apply this to God's relation to us as well. God loves us for no reason or gain. God did not elect us because of qualities in ourselves. As Deuteronomy 7:7 says: "The Lord did not set his affection on you and choose you because you were more numerous than other people, for you were the fewest of all peoples, but it was because the Lord loved you and kept the oath he swore to your forefathers." And God does not treat us as we deserve in view of our sins, sings Psalm 103:10. God keeps to God's promises in spite of Israel's unfaithfulness. Even if we are faithless, God will remain faithful. God cannot disown God self (2 Tm 2:12).

That does not imply "cheap" grace. The case of God is not as Voltaire formulated it: "God will forgive it. That's his job." Only people who do not know about the depth of faithfulness can live that way, like the people criticised by Voltaire. It is the other way around: in order that the grace of God can come out, sin has to remain sin. We can never propagate sin as an ideal, just as we should not propagate poverty as an ideal. Sin is terrible. It is even more grievous to God than to us. The problem is precisely that we do not take it as seriously as God does. God is tested every day by humans, as Job was tested by God. Sinning seems to be our job - even our being. But it is exactly this being that God is faithful to - not for any reason in us. There are no ulterior motives in God's love for us.

We live in a world where people suffer, and it is precisely in that suffering that their godliness emerges. We live in a world with sin, and it is precisely in that world that God's grace emerges. Neither suffering nor sin is ever willed. They are horrible to both God and to godly people. Christian faith confesses that precisely at this point God and human beings meet each other: at the cross of Christ, God who suffers and is cursed on behalf of us, and a 


\section{Religion without ulterior motive}

human being who dies as one lost - forsaken by God, and it is exactly at that moment that He entrusts Himself to God's hands.

God's history with His people is the history of Jesus. Sometimes we see it reflected in human stories. Again it is a Jewish story that puts us on the track. In Yad Vasjem, the museum of the Sjoa' in Jerusalem, there is a memorial for a Polish rabbi. He refused to be saved. He preferred to go to the gas chambers together with the orphan children he cared for. The godly dies together with his children. That is the deepest expression of human dignity. The holy God dies in a place of execution, together with sinners. That is the deepest expression of divine glory. That is the King of the Jews (Mk 15:26; Mt. 27:37; Lk 23:38; Jn 19:19).

We cannot explain why it is that way. Why could God not create a perfect world? Discussions like that involve fruitless speculation. According to both Irenaeus and Calvin, we should reject that kind of curiosity. We only have to deal with one reality: the reality of this God, this creation and these people He elected to be loved to the last. We cannot understand it. If we could, we would have an explanation for God's ultimate being. That would be a blasphemy - that God's being would be dependent on our arguments. God is just as $\mathrm{He}$ is. $\mathrm{He}$ is who $\mathrm{He}$ is. $\mathrm{He}$ is - that is the only reason to glorify Him.

\section{Works consulted}

Balke, W 1973. Calvijn en de doperse radicalen. Amsterdam: Ton Bolland.

Calvin, J 1509-1564. Institutes. A new translation by Henry Beveridge, 1962. London: James Clarke.

Classen, W F 1931. s v Volk und Volkstum. Die Religion in Geschichte und Gegenwart, 5, 2.Aufl, 1630-1632. Tübingen: Mohr.

Heschel, A J 1980. Gott sucht den Menschen: Eine Philosophie des Judentums. Neukirchen-Vluyn: Neukirchener Verlag.

Hirsch, S 1854. The authority of tradition: Religion allied to progress, in Frank, D H Leaman, O \& Manekin, C H (eds) 2000, The Jewish philosophy reader, 391397. London: Routledge.

Justin M, S 1987. Apology: Introduction, texte critique, traduction, commentaire et index par Andre Wartelle. Paris: Etudes Augustiniennes.

Kähler, E 1936. Israel unter den Völkern. Zürich: Humanitas.

Kuyper, A 1930. Souvereiniteit in eigen kring. $3^{\text {rd }}$ Ed. Kampen: Kok.

Migne, J-P 1855. Patrologia Graeca. Paris: Garnier.

Origen, Contra Celsum, in Migne, J-P, PG 11:115-414.

Smith, A D 2003 Chosen people. Oxford: Oxford University Press.

Van de Beek, A 1992. Rechtvaardiger dan God: Gedachten bij het boek Job. Nijkerk: Callenbach.

Van de Beek, A 1997. A life in freedom, in Van Egmond, A \& Van Keulen, D (eds), Freedom, 9-24. Baarn: Callenbach. 
Van de Beek, A 2003a. Calvinism as an ascetic movement, in Alston, W M \& Welker, M (eds), Reformed theology: Identity and ecumenicity, 205-222. Grand Rapids, MI: Eerdmans.

Van de Beek, A 2003b. Beyond the unfounded optimism of equity. Unpublished Paper presented at the conference on Living and affirming with differences of the Moluks Theologisch Beraad, the Hendrik Kraemerinstituut, the Faculty of Theology of the Vrije Universiteit Amsterdam and the International Reformed Theological Institute, Houten/Utrecht/Amsterdam. To be published in Studies in Reformed Theology, 12.

Van Unnik, W C van 1951. Het Jodendom in de diaspora, in Waszink, J H Van Unnik, W C \& De Beus, C (eds), Het oudste christendom en de antieke cultuur, I. Haarlem: Tjeenk Willink. 